quality long-distance telephone communications. Further, their advent makes practical, in many instances, provision for the introduction of television networks on an international scale.

Advances during the first two periods were effected largely with material and apparatus placed in the field, that is, 'outside plant' ; those of the third period depended largely on central office equipment. While an important element in progress during the fourth period doubtless must be credited to central office equipment, such as the terminal apparatus for the coaxial and twelve-channel systems, it appears that a new essential factor will be the adaptation of apparatus heretofore regarded as central office equipment to utilization in the field. This new apparatus, as previously indicated, has been embodied in unattended repeater stations.

\section{ASSOCIATION OF UNIVERSITY PROFESSORS AND LECTURERS OF ALLIED COUNTRIES}

\section{GENERAL MEETING}

$\mathrm{T}$ HE Association of University Professors and Lecturers of Allied Countries in Great Britain marked its third general meeting with a whole-day session on December 16. The Association, which now comprises 230 members, works through twelve sections (see NaTURE, December 12, p. 692), most of which had separate meetings, followed by a general meeting of all members. At this general reunion, reports were presented by the chairmen of groups of sections, and general recommendations made. Thus the deliberations of the individual sections were brought together, to present an inter-Allied view on matters in different domains of actual knowledge. Complete liberty of academic thought and spirit, with such freedom of speech as would be impossible in the countries of continental Europe, characterized the proceedings.

The main points of the aims and work accomplished by the groups of sections were as follow :

Arts : Law, economics, humanities and history, such as studies of comparative law; the position of economic science in the different countries; establishment of a scientific basis for economic planning; the possibility of reaching an agreement on the question of general history ; and considerations relating to an international language.

Science: Inter-Allied collaboration for the establishment of an international academy of medicine; the establishment of an international body of information, and the co-ordination of inventions and scientific discoveries in general; an international research centre; collaboration with the Leith-Ross Committee; the establishment of liaisons with British organizations which are studying the planning and reconstruction of Europe; the examination of problems concerning the moral and material sustenance of scientific men in comparison with the manual worker.

General : Dealing with general subjects and with questions of general interest for university men; for example, contacts between British and foreign scholars in Great Britain during the War ; the promotion of international collaboration after the War; reconstruction and planning of science and learning in the occupied countries, and the problems of the re-education of youth after the War in Allied and enemy countries.

Prof. R. Douglas Laurie, honorary general secretary of the Association of University Teachers, announced that all members of the Association of University Professors and Lecturers of Allied Countries were invited to become honorary members of the Association of University Teachers. This will lead to closer working and social unity between British and Allied professors and lecturers.

In the course of an address by the president of the Association, Prof. S. Glaser (Poland), the various steps were mentioned which the Association has so far been able to make to promote the necessary collaboration between scientific workers and other scholars of the Allied countries. The reconstruction of moral values as well as the rebuilding of institu tions of all categories constitutes, he said, one of the aims towards which the Association is exerting its efforts. This is being carried out, so far as possible, with a profound sense, both spiritual as well as cultural, of the importance of European society as a whole after the War.

It was decided at the general meeting, among other matters, that a conference on a fairly large scale on education should be arranged for the early spring 1943, and a sub-committeo under the chairmanship of Sir Alfred Zimmern (Oxford) has been appointed for this purpose.

In NATURE of December 12, a list was given of the general officers and chairmen of sections of the Association. The following can now be added to the list. Section 3: Reconstruction of science and learning in the occupied countries (Chairman: $\mathbf{M r}$. Willard Connely). Section 9: Medicine as distinct from general science (Chairman: Dr. Jean-Edouard Bigwood). Section 10: Technical Science and Engineering, has been placed in Section 6 (Science).

Thanks to the efforts of the Association, very useful collaboration between members in the field of learning and scientific research is being established among the various professors and lecturers of the Allied countries. It provides an opportunity of establishing unity in the true sense of the word, namely, with intellectual and moral solidarity; a fact the importance of which will be appreciated by scientific men and other scholars of the Allied countries, wherever their interests in the plans and problems of to-morrow may lie.

\section{THE WAIRARAPA (NEW ZEALAND) EARTHQUAKE OF JUNE 24, 1942} PRELIMINARY report on some of the seismo-
Jogical aspects of the Wairarapa earthquake of
June 24, 1942, has been issued by the Department
of Scientific and Industrial Research, New Zealand
(Dominion Observatory Bull. S-66, Wellington, New
Zealand, September, 1942).
Following a rather strong fore-shock at 8.14 p.m.
on June 24, the major shock occurred without
further warning at $11 \mathrm{~h}$. $16 \cdot 5 \mathrm{~m}$. p.m. (New Zealand
Daylight Saving Time). Considerable damage to old
or poorly constructed buildings occurred at Masterton,
where the intensity appeared to be $8+$ on the Rossi-
Forel scale. There were no fatal casualties, though
minor injuries were caused by falling debris. Inten-
sity 8 on the Rossi-Forel scale was attained over a. 
large part of Wairarapa, and the intensity in Wellington City was between 7 and 8 . There was evidence of surface faulting at a point 8 miles east of Masterton, and running from a point about 10 miles north-northeast of this point to about 30 miles south of it.

The area over which the shock was felt extended from about Auckland in the north to Dunedin and Queenstown in the south, the latter place being 470 miles from the epicentre. The epicentre, determined from seismographic evidence and supported by field evidence, was near lat. $40 \cdot 9^{\circ} \mathrm{S}$., long. $175 \cdot 8^{\circ} \mathrm{E}$. The focal depth was probably normal. Earthquake sounds, usually low rumblings, and luminous phenomena, usually blue or green flashes, were reported from numerous places in both islands.

Up to June 30, 418 aftershocks were recorded by the seismographs at Wellington, 300 of these being within 24 hours after the main shock. None of these shocks was a large one, but on August 2 at 00h. $34 \mathrm{~m}$. a.m. N.Z.D.S.T. a shock nearly as severe as the initial one occurred. Some further damage was caused, chiefly to buildings previously damaged, and occasionally to buildings repaired after the first shock in which the mortar had not had time to harden.

The Wairarapa district has been shaken previously by earthquakes on March 5, 1934, August 6, 1917, April 12, 1913, August 4, 1904, and in 1855, epicentres not always being in the same place.

\section{FORTHCOMING EVENTS}

(Meetings marked with an asterisk are open to the public)

Tuesday, February 23

ROYAI ANTHROPOIOGICAI INSTITUTE (at 21 Bedford Square, ROYAL ANTHROPOLOGICAL INSTITUTE (at 21 Bedford Square, London, W.C.1), at

Royal College of Physiorans (at Pall Mall East, London, S.W.1), at 2.15 p.m.-Dr. S. A. Henry : "The Health of the Factory Worker in War Time" (Milroy Lectures, 1).

Chadwiok PUblic Lecture (at the London School of Hygiene and Tropical Medicine, Keppel Street, London, W.C.1), at 2.30 p.m.Prof. M. Greenwood, F.R.S.: "Social and Industrial Environment and Disease".

Manchester LtTerary aND Phimosophical Society (in Room No 7 The University, Manchester), at 5 p.m.-Dr.J. H. Shaxby : "The Human Senses, especially Sight and Colour Vision".

INSTITCTION OF CIVII ENGINEERS (RAILWAY ENGIN EIRING DIVISION) (at Great George Street, Westminster, London, S.W.1), at 5.30 p.m. Mr. A. S. Quartermaine: "Railway Construction in Great Britain under War Conditions".

\section{Wednesday, February 24}

RoYal Socrery of ARTs (at. John Adam Street, Adelphi, London, W.C.2), at 1.45 p.m.-Mr. P. E. Cross: "Agriculture To-day and To-morrow", 5 : "Extension of Market Gardening into Agriculture".

Thursday, February 25

BRITISH SOCIETY FOR INTERNATIONAL BIRLIOGRAPHY (at the Science Musum Exhibition Road, South Kensington, London, S.W.7), at 2.15 p.m.-Annual General Meeting. Mr. E. Lancaster-Jones: "The Operation of a Microfllm Service". Symposium on "The Classification of Maps and Plans for Territorial Planning" (to be opened by Mr. E. Carter). RoYAl College of PHYsicians (at Pall Mall Fast, London, S.W.1),
at 2.15 p.m. $\rightarrow$ Dr. S. A. Henry: "The Health of the Factory Worker in War Time" (Milroy Lectures, 2).

\section{Friday, February 26}

ROYAL INSTITUTION (at 21 Albemarle Street, London, W.1), at 5 p.m.-Prof. L. P. Abercrombie : "The Inter-Action between Town 5 p.m.-Prof. L. P. Aber.

CHEMTCAL Sooletx (in the Lecture Theatre of the Chemistry Department, University College of North Wales, Bangor), at 5.30 p.m.Prof.'T. P. Hilditch, F.R.S.: "Some Aspects of the Chemical Constitution of Milk Fats;.

Chemical Socinty (JOINT MaETING WITH THE UNIVRRSITY ChEMTCAI SOcIETX) (in the Chemical Lecture Theatre, The University, Sheffield), at 5.30 p.m.-Prof. J. M. Gulland: "Aspects of Nucleotide Chemistry" (Tildev Lecture)
Saturday, February 27

Malacological Societr (at the : Linnean Society, Burlington House, Piccadilly, London, W.1), at 2.30 p.m.-Annual General Meeting and Commemoration of the 50th Anniversary of the Society's Foundation.

Iight RaILWAy Transport LEAGUE (at Fred Tallant Hall, Room $J$, Drummond Street, Iondon, N.W.1), at 3 p.m.-Dr. Hugh Nicol: "A' Scientist Looks at Transport".*

\section{APPOINTMENTS VACANT}

ApPuICATrons are invited for the following appointments on or before the dates mentioned:

assistant Master to Teach Mathematics, WITh some Physics or Chemistry, in the Sheffield Junior Technical School for BoysThe Director of Education, Education Office, Leopold Street, Sheffield 1 (February 24).

LEOTURER IN ELECTRICAL ENGINEERING--The Clerk to the Governors, Heanor Mining and Technical School, 30 Mansfeld Road, Heanor, Derbyshire (February 24)

TEAcher (MAN) of PHYsics in the Junior Technical School-The Principal; Technical College, Church Street, Barnsley (February 26). ChaIr of Mining-The Secretary, The University, Edmund Street, Birmingham 3 (March 1).

INSTRUCTOR IN BEEKEEPIN - The Education Officer, County Hall, Wakefield (March 1).

ASSISTANT WITH KNOWLEDGE OF RUSSIAN, GERMAN AND OTHER GUROPEAN LANGUAGES-The Deputy Director, Imperial Bureau of Animal Breeding and Genetics, King's Buildings, Edinburgh 9 (March 5).

Master To TEACH MATHEMatics AND Science in the new Junior Technical School Building Course for Boys, Bingley Technical School -The Divisional Education Officer, Education Offces, Bingley, Yorks. (March 7).

Sir Dorab Tata Reader in Pharmaceuticad Chemistry in the Department of Chemical Technology-The Registrar, University of Bombay, Bombay, India (A pril 15).

Teacher of ENGINeering Workshop Practice and General ENGINEERING SUBJEOrs in the Burton-on-Trent Technical Institute and Junior Technical School-The Secretary and Director of Education, Education Offices, Guild Street, Burton-on-Trent.

RESEARCH ASSISTANT-The Director, Research Association of British Flour-Millers, Old London Road, St. Albans, Herts.

\section{REPORTS and other PUBLICATIONS} (not included in the monthly Books Supplement)

\section{Great Britain and Ireland}

Selected Papers from the Royal Cancer Hospital (Free) and the Chester Beatty Research Institute. (Published by order of the Governors of the Royal Cancer Hospital (Free), London.) Vol. 1, 1935-1939. Pp. xiit484. (London: Royal Cancer Hospital (Free).) 1935-1939. Pp. xii 484. (London: Royal Cancer Hospital (Free).)
[201 Thorley's Farmer's Diary and Almanack, 1943. Pp. 48. (London: Joseph Thorley, Ltd.) $6 d$. [201

\section{Other Countries}

Indian Forest Bulletin No. 112 : Interim Report on the Manufacture of Kraft Paper from Bamboos By M. P. Bhargava and Chattar Singh.
Pp. $v+13$. (Delhi : Manager of Publications.) 7 annas : $8 d$. Canada: Department of Mines and Resources, Mines and Geology Branch : Geological Survey. Paper 42-7: Preliminary Map, Takla, British Columbia. By J. E. Armstrong. 10 cents. Paper 42-11 : The Pinchi Lake Mercury Belt, British Columbia. By J. E. Armstrong. Pp. 18+map. 10 cents. Paper 42-12: Preliminary Map, VassanDubuisson, Abitibi County, Quebec. By G.W. H. Norman. 10 cents. Paper 42-13 : Preliminary Map, Beresford Lake, Manitoba. By C. H. Stockwell. 10 cents. Paper 42-14: Preliminary Map, Gem Lake, Manitoba By C. H. Stockwell. 10 cents. (Ottawa: King's Printer.) [81 Reports of the Biochemical Research Foundation of the Franklin Institute. Vol. 6, 1940-1941. (Newark, Del.: Biochemical Research Fund.)

[151

Commonwealth of Australia: Council for Scientific and Industrial Research. Bulletin No. 146: An Analysis of the Outbreaks of the Australian Plague Locust (Chortoicetes terminifera Walk) during the Seasons 1937-38 and 1938-39. By Dr. K. H. L. Key. Pp. 88. Pamphlet No. 110: The Main Virus Diseases of the Potato in Victoria. By Dr. J. G. Bald and A. T. Pugsley. Pp. $40+4$ plates. Pamphlet No. 114 : Plant Introdution. 1 A notes on Outstanding Species, by Dr. A. McTaggart : 2 : Prellminary Selection and Evaluation of Pasture Species at Lawes (Queensland), by T. B. Paltridge.
Pp. 30. (Melbourne: Government Printer.) Faculdade de Ciências da Universidade do Pôrto: Instituto de Antropologia. Da Raca e do Espérito. Por Prof. A. A. Mendes Corrêa. Pp. viîi + 306. A Fscola Antropológica Portuense. Por Prof.A.A. Mendes Corrêa. Pp. 60+19 plates. (Pôrto: Universidade do Pôrto.) [201 Asociación Espanola para el Progreso de las Ciencias. Perspectivas duma Antropologia Citológica. Por el Dr. A. A. Mendes Corrêa. Pp. 16. (Madrid Asociación Espanola para el Progreso de las 